\title{
ISOLATION OF A NEW PEPTIDE ANTIBIOTIC, 339-29 \\ (STUDIES ON ANTIBIOTICS FROM THE GENUS BACILLUS. XIV')
}

\author{
Jun'ichi Shoj, Hiroshi Hinoo, Yoshinaru Wakisaka, Kenzo Koizumi, \\ Mikao Mayama and Shinzo MatsuUra \\ Shionogi Research Laboratory, Shionogi \& Co., Ltd., \\ Fukushima-ku, Osaka 553, Japan \\ (Received for publication March 29, 1976)
}

\begin{abstract}
A new antibiotic, named 339-29, active against Gram-positive bacteria was isolated from a strain of Bacillus pumilus. The hydrochloride is soluble in water and aqueous alcohols. The antibiotic is a basic peptide containing valine (3), isoleucine (1), leucine (2), tyrosine (1), lysine (3) and a fatty acid.
\end{abstract}

In the course of our screening program for new antibiotics from the genus Bacillus ${ }^{1)}$, an antibiotic active against Gram-positive bacteria was isolated from the culture broth of a strain numbered 33929. Taxonomical characterization identified the strain as B. pumilus.

Characterization and fermentation of strain 339-29, and isolation and characterization of the antibiotic are described here.

\section{Characterization of Strain 339-29}

The characteristics of strain 339-29, from which it was identified as B. pumilus, is described below. 1. Morphology

(1) Vegetative cells $\left(28^{\circ} \mathrm{C}, 1 \sim 2\right.$ days): Gram-positive rods on nutrient agar are $0.6 \sim 1.0$ (mostly $0.7) \times 2.0 \sim 4.0$ microns with rounded ends. They occur singly or in mass and are motile.

(2) Spores and sporangia $\left(28^{\circ} \mathrm{C}, 1 \sim 2\right.$ days $)$ : Spores on nutrient agar are mostly $0.7 \times 1.8$ microns, not easily stainable, subterminal to central, cylindrical. Sporangia are not swollen.

2. Cultural Characters

(1) Colony on No. 172 agar medium* $\left(28^{\circ} \mathrm{C}, 1 \sim 3\right.$ days): Circular $(3 \sim 6 \mathrm{~mm})$, smooth, convex, slightly echinulated soft, translucent to opaque.

(2) Nutrient agar slant $\left(28^{\circ} \mathrm{C}, 2 \sim 3\right.$ days): Growth moderate, filiform, surface shining at early changing to dull at late. Butyrous consistency, grayish-white color and opaque density. Diffusible and non-diffusible pigment are not observed.

(3) Nutrient broth $\left(28^{\circ} \mathrm{C}, 1 \sim 5\right.$ days): Uniform, significant growth. A ring formation is observed. 3. Physiological Characters

(1) Relation to oxygen $\left(28^{\circ} \mathrm{C}, 1 \sim 2\right.$ days): O-F test on GPYB-agar stab** is aerobic. Acid but no gas formation is observed from glucose.

* No. 172 Agar: Soluble starch $2.0 \%$, glucose $1.0 \%$, Casamino acids $0.5 \%$, yeast extract $0.5 \%, \mathrm{CaCO}_{3}$ $0.1 \%$, agar $1.2 \%(\mathrm{w} / \mathrm{v}), \mathrm{pH} 6.8$.

** GPYB-agar: Glucose $1.0 \%$, peptone $0.5 \%$, yeast extract $0.2 \%$, beef extract $0.3 \%$, agar $0.4 \%(\mathrm{w} / \mathrm{v})$, $\mathrm{pH}$ 6.6. 
(2) Temperature relations (Gly-IM agar, ${ }^{*} 1$ day): Optimum is approximately $37^{\circ} \mathrm{C}$. It does not grow at $50^{\circ} \mathrm{C}$.

(3) Citrate utilization $\left(28^{\circ} \mathrm{C}, 1 \sim 2\right.$ days): No growth on KOSER's synthetic medium.

(4) Starch hydrolysis $\left(28^{\circ} \mathrm{C}, 1 \sim 7\right.$ days): Negative.

(5) Gelatin stab $\left(28^{\circ} \mathrm{C}, 1 \sim 20\right.$ days): Liquefied strongly.

(6) Casein hydrolysis $\left(28^{\circ} \mathrm{C}, 1 \sim 2\right.$ days $):$ Positive.

(7) Litmus milk $\left(28^{\circ} \mathrm{C}, 2 \sim 30\right.$ days $)$ : Peptonized slowly.

(8) Nitrate reduction to nitrite $\left(28^{\circ} \mathrm{C}, 2\right.$ days $)$ : Positive.

(9) Acetylmethylcarbinol production $\left(28^{\circ} \mathrm{C}, 2 \sim 4\right.$ days): Negative at 2 day and slightly positive at 4 day.

(10) $\mathrm{H}_{2} \mathrm{~S}$ formation $\left(28^{\circ} \mathrm{C}, 2 \sim 7\right.$ days, Difco peptone iron agar): Negative.

(11) Urease activity $\left(28^{\circ} \mathrm{C}, 1 \sim 7\right.$ days): Weakly positive.

(12) Oxidase $\left(28^{\circ} \mathrm{C}, 1\right.$ day): Positive.

(13) Catalase $\left(28^{\circ} \mathrm{C}, 1\right.$ day): Positive.

(14) $\mathrm{NaCl}$ broth $\left(28^{\circ} \mathrm{C}, 1 \sim 2\right.$ days): No growth in 5 and $10 \% \mathrm{NaCl}$ broth.

(15) Carbohydrate cleavage $\left(28^{\circ} \mathrm{C}, 1 \sim 11\right.$ days): Acid formation is observed from $\mathrm{D}$-glucose only. No acid formation from L-arabinose, D-xylose, L-rhamnose, D-ribose, D-mannose, D-galactose, D-fructose, sucrose, maltose, lactose, raffinose, dextrin, starch, glycogen, inulin, glycerol, $m$-inositol, adenitol, mannitol, sorbitol, salicin and $\alpha$-methylglucoside.

4. Speciation

From the above descriptions, we concluded that strain 339-29 is a strain of Bacillus pumilus ${ }^{2,3}$. This culture is a little different from B. pumilus ATCC 7061, i.e. 339-29 reduce nitrate to nitrite but ATCC 7061 does not and V-P reaction of ATCC 7061 is strong but 339-29 is very weak. However, all of other characters of 339-29 is similar to B. pumilus ${ }^{2,3)}$.

Procedures for the taxonomic study were in accordance with those described in the Manual of Microbiological Method ${ }^{4)}$ and Identification Method for Microbiologist ${ }^{5)}$ except where indicated otherwise.

\section{Fermentation}

Spores of strain 339-29 were inoculated into $120 \mathrm{ml}$ of a medium containing glucose $0.5 \%$, peptone $1.0 \%$ meat extract $0.5 \%$ and sodium chloride $0.3 \%(\mathrm{pH} 7.0)$ in a $500-\mathrm{ml}$ shake flask, and shakecultured for 24 hours at $27^{\circ} \mathrm{C}$. About $5 \mathrm{ml}$ of the culture were then seeded into $120 \mathrm{ml}$ of a medium consisting of glucose $1.0 \%$, glycerin $0.25 \%$, soy bean meal $1.0 \%$, peptone $0.25 \%$, and sodium chloride 0.3 $\%(\mathrm{pH} 7.0)$ in a flask, which was shake-cultured for 48 hours at $27^{\circ} \mathrm{C}$.

\section{Isolation and Purification}

The culture broth ( 5 liters) was filtered by the aid of Hyflo Super-Cel $(200 \mathrm{~g})$. The filter cake was extracted with $60 \%$ aqueous acetone. The extract was evaporated under reduced pressure to nearly an aqueous solution, which was then extracted with $n$-butanol at $\mathrm{pH} 8.5$. The culture filtrate was also extracted with $n$-butanol at $\mathrm{pH} 8.5$. These $n$-butanol extracts were combined and concentrated under

* Gly-IM Agar: Glycerol $0.5 \%$, peptone $0.25 \%$, beef extract $0.25 \%$, yeast extract $0.25 \%$, Bacto soytone $0.25 \%, \mathrm{NaCl} 0.3 \%$, agar $1.25 \%(\mathrm{w} / \mathrm{v}), \mathrm{pH} 6.8$. 
reduced pressure to a small volume. To the concentrate, ethyl acetate was added, and the antibiotic was transferred into water slightly acidified ( $\mathrm{pH}$ 2.0) with hydrochloric acid. The antibiotic was again extracted with $n$-butanol at $\mathrm{pH}$ 8.5. The $n$-butanol solution was concentrated to a syrup, from which the antibiotic was precipitated as a crude powder $(2.0 \mathrm{~g})$ by addition of ethyl ether.

The crude powder $(500 \mathrm{mg})$ was applied to three silica gel GF plates $(20 \times 100 \mathrm{~cm}$, thickness $750 \mu)$ and developed with chloroform - ethanol - 14\% aqueous ammonia (4: 7:2). The separated zone of the antibiotic was detected by a UV-lamp and extracted with $50 \%$ aqueous methanol acidified to $\mathrm{pH}$ 2.0 with hydrochloric acid. The extract was evaporated to a nearly aqueous solution and the antibiotic was transferred to $n$-butanol at $\mathrm{pH} 2.0$. The $n$-butanol solution was washed with water at $\mathrm{pH} 2.0$ and concentrated to a syrup. 339-29 hydrochloride was precipitated by addition of acetone as a colorless amorphous powder (110 mg).

The preparation thus obtained gave a single round spot on a silica gel GF plate; Rf $c a .0 .20$ with chloroform - ethanol - $14 \%$ ammoniacal water (4: $7: 2$ ) and Rf $c a .0 .35$ with chloroform - ethanol - $10 \%$ acetic acid $(4: 7: 2)$.

\section{Characterization}

The basic nature of 339-29 was indicated by paper electrophoresis carried out with buffer solutions of different pHs. The hydrochloride is a colorless amorphous powder, m.p. $205 \sim 212^{\circ} \mathrm{C}$ (dec.). Elemental analysis: $\mathrm{C}, 54.12 ; \mathrm{H}, 8.99 ; \mathrm{N}, 12.37 ; \mathrm{Cl}, 6.70 .[\alpha]_{\mathrm{D}}^{26.0}-27.1 \pm 1.4^{\circ}(c 0.491, \mathrm{MeOH})$. $\lambda_{\mathrm{max}}^{\mathrm{MeOH}}: 225 \mathrm{~nm}\left(\mathrm{E}_{1 \mathrm{~cm}}^{1 \%} 128\right), 278 \mathrm{~nm}\left(\mathrm{E}_{1 \mathrm{~cm}}^{1 \%} 9.6\right), 285 \mathrm{~nm}$ shoulder ( $\left.\mathrm{E}_{1 \mathrm{~cm}}^{1 \%} 7.6\right)$ (Fig. 1). The infrared absorption spectrum (Fig. 2) shows typical peptide bands. The hydrochloride is soluble in water, methanol and aqueous $n$-butanol, but slightly soluble or insoluble in acetone, ethyl acetate, chloroform and ethyl ether. Ninhydrin, Dragendorf, Pauly, and SAKaguchi reactions are positive.

339-29 hydrochloride was hydrolyzed with constant boiling hydrochloric acid in a vacuumsealed tube for 48 hours at $110^{\circ} \mathrm{C}$. The hydrolyzate was analyzed by an amino acid analyzer, Hitachi Model KLA-5. The following amino acids were found ( $\mu$ moles per mg of antibiotic): Valine (1.66), isoleucine $(0.57)$, leucine (1.25), tyrosine (0.52), lysine(1.87). This suggested that the molar contents of these amino acids are valine (3), isoleucine (1), leucine (2), tyrosine (1) and lysine (3), and the molecular weight is ap-

Fig. 1. Ultraviolet absorption spectrum of 339-29 hydrochloride (in methanol).

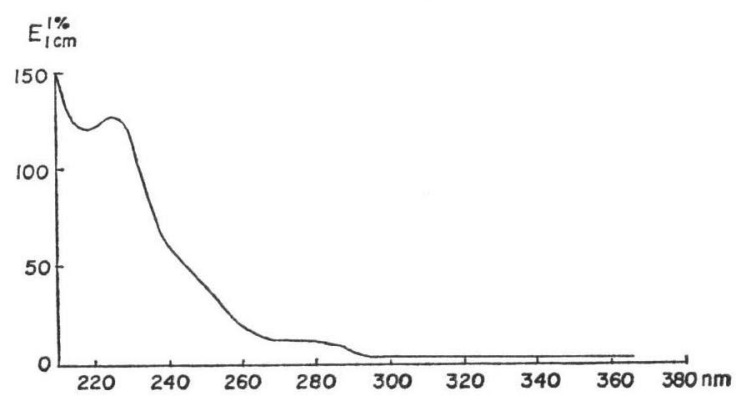

Fig. 2. Infrared absorption spectrum of 339-29 hydrochloride (KBr).

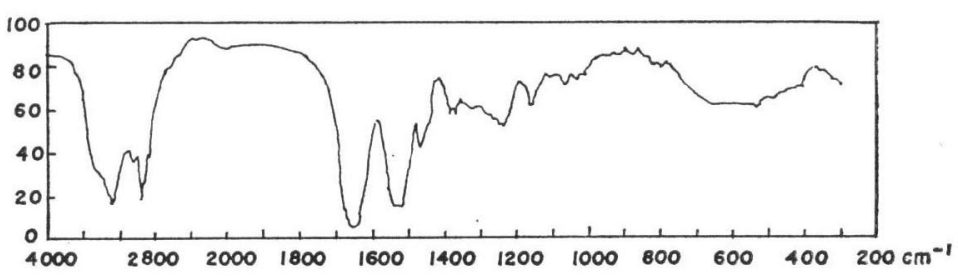


proximately 1,700 .

The hydrolyzate was extracted with ethyl ether. The extract was methylated and subjected to GLC for detection of fatty acid residues. Following the experimental method described in our previous publication ${ }^{6)}$, a predominant peak was observed. The chromatogram did not alter after hydrogenation procedure with the preparation. The retention time of the peak was compared with those of reference fatty acid methyl esters in the usual way ${ }^{6}$. When a column packed with $15 \%$ diethylene glycol succinate polymer or Chromosorb W was used for the analysis, it nearly corresponded to that of a normal fatty acid methyl ester with carbon number ten $\left(n-\mathrm{C}_{10}\right)$. However, when a column packed with $5 \%$ diethylene glycol succinate polymer on Chromosorb W was used, the correspondence shifted to that of a fatty acid ester with carbon number nine $\left(n-\mathrm{C}_{\theta}\right)$. This means that the presence of some kind of fatty acid in the antibiotic is sure, but it is not a simple fatty acid. Elucidation of the fatty acid component of the antibiotic will be made in our future studies.

The above data indicated that 339-29 is a basic acylpeptide. Comparison with known peptide antibiotics from Bacillus species, makes it evident that none is identical or similar to the antibiotic with respect to the constituent amino acids. Thus, it is concluded that 339-29 is a new peptide antibiotic produced by Bacillus species.

339-29 was active against Gram-positive bacteria as shown in Table 1. When the antibiotic was administered intraperitoneally three times ( 0,4 and 8 hours after infection) to mice infected with Streptococcus pyogenes, a curative effect was observed $\left(\mathrm{ED}_{50}: c a .0 .3 \mathrm{mg} / \mathrm{kg} \times 3\right)$, but not when it was administered subcutaneously. 339-29 showed an approximate $\mathrm{LD}_{50}$ value of $5 \sim 10 \mathrm{mg} / \mathrm{kg}$ to mice via the intraperitoneal route.

\section{References}

1) Shoir, J.; R. Sakazaki, Y. Wakisaka, K. Kolzumi, M. Mayama, S. Matsuura \& K. Matsumoto: Isolation of a new antibiotic, laterosporamine. (Studies on antibiotic from the genus Bacillus. XIII). J. Antibiotics 29: 390 393, 1976

2) Buchanan, R. E. \& N. E. Gibbons, Edited: Bergey's Manual of Determinative Bacteriology. Eighth Edition, The Williams and Wilkins Company, Baltimore, 1974

3) Skerman, V.B. D., Edited: A Guide to the Identification of the Genera of Bacteria. Second Edition, The Williams and Wilkins Company, Baltimore 1967

4) Society of American Bacteriologists: Manual of Microbiological Methods. McGraw-Hill, New York, 1956

5) Gibbs, B. M. \& D. A. Shapton, Edited: Identification Methods for Microbiologists. Part B. Academic Press, London-New York, 1968

6) ShoJi, J. \& H. Otsuka: Studies on tsushimycin. II. The structures of constituent fatty acids. J. Antibiotics 22: 473 479, 1969 